
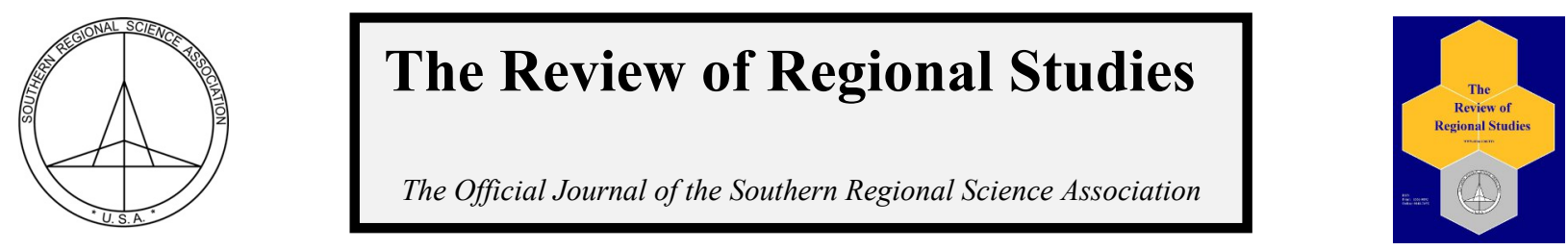

\title{
Economic Growth and Tax and Expenditure Limitations
}

\author{
Lindsay N. Amiel ${ }^{\mathrm{a}}$, Steven Deller ${ }^{\mathrm{a}}$, and Judith I. Stallmann ${ }^{\mathrm{b}}$ \\ ${ }^{a}$ Department of Agricultural and Applied Economics, University of Wisconsin-Madison, USA \\ ${ }^{b}$ Department of Agricultural and Applied Economics, Rural Sociology, Public Affairs, University of Missouri, USA
}

\begin{abstract}
Using a Barro-type empirical growth framework we explore the relationship between tax and expenditure limitations (TELs) and the economic growth of U.S. states. The model uses a panel of annual data for the 50 states from 1990 to 2010, with a variable parameter specification coupled with a dynamic Generalized Method of Moments (GMM) panel estimator. In general, more restrictive tax and expenditure limitations can influence the growth process; however, this relationship varies over levels of income and type of TEL.
\end{abstract}

Keywords: tax and expenditure limits, economic growth, convergence

JEL Codes: R11, E62

\section{INTRODUCTION}

There is a long and rich theoretical and empirical literature focused on how government expenditures and fiscal policies influence economic growth. The literature is extremely broad, ranging from the impact of the size of the government, measured by government spending as a share of the economy, on economic growth to the role of taxation on firm location decisions. Despite the breadth of the literature, there are several patterns in the literature that can be highlighted. First, public services are a normal good and as the economy grows the demand for services also grows. In addition, downward pressures on economic growth are generated if the absolute size of government grows faster than the overall economy over the long term (Bergh and Henrekson, 2011). Ceteris paribus, the rate of growth in the public sector should be slower than the overall growth rate of the economy.

Second, a determinant of growth dynamics is the expenditure mix of services provided by the government. Research suggests that expenditures on "productive" public services, such as infrastructure, education and health care, have a positive impact on economic growth while expenditures on "non-productive" services such as transfer payments, can place a drag on economic growth (Barro, 1991, 1997; Mofidi and Stone, 1990; Reed, 2008). Third, as Lynch (2004: page 12) argues "[b]usinesses need to know that they can rely on high-quality, welladministered public services to facilitate the conduct of their enterprises," The literature examining the allocative efficiency of governments at the local level (i.e., Oates, 1969, Brueckner, 1979, 1982, 1983; Henderson, 1980, 1985; Deller 1990a, 1990b; Deller and Maher, 2009) suggests that perceptions of efficiency matter. If local tax payers believe they are receiving

Amiel is a graduate student in the Department of Agricultural and Applied Economics, University of Wisconsin-Madison, Madison, WI, USA. Deller is Professor and Community Economic Development Specialist at University of Wisconsin-Madison, Madison, WI, USA. Stallmann is Professor of Agricultural and Applied Economics, Rural Sociology, and Public Affairs at University of Missouri, Columbia, MO, USA. Corresponding Author: S. Deller E-mail: scdeller@wisc.edu 
services congruent with taxation levels, taxes do not place downward pressure on economic performance. If there is a perception that there is waste and inefficiency in the production of services, then there is a potential for downward pressure on economic growth. A positive business climate hinges on a level of trust and confidence that the government will make good fiscal policy decisions and will provide a certain level of stability in fiscal policies and enforcement of regulations.

Distrust over government taxation and public expenditures has led to legislation constraining taxation as well as to major shifts in the national political arena, such as the formation of the Tea Party Movement. This line of thinking is embodied in the LeviathanNiskanen-Buchanan model of government spending; government is inherently inefficient because elected officials and government bureaucrats cannot be trusted to keep taxes and spending under control due to the influence of special interest groups and the reluctance to terminate or significantly reduce existing programs.

The perception of government waste and inefficiency has led to the passage of tax and expenditure limits (TELs) in many states to restrict and tightly control government spending. TELs are "formula based budgeting requirements that apply specific limits to state and/or local revenues, expenditures or appropriations" (Brome et al, 2006). At the state level, tax and expenditure limitations (TELs), such as California's Proposition 13, Massachusetts's Proposition $2^{1 / 2}$ and Colorado's Taxpayers Bill of Rights (TABOR), were implemented in response to public perception that officials lack fiscal discipline and cannot be trusted to control taxation and spending. Today, 46 states have some form of constitutional or statutory limits on the ability of the state and/or local governments to raise taxes and/or expenditures (Mullins and Wallin, 2004; Deller and Stallmann, 2007; Kioko, 2011). These TELs range from simple open meeting laws to strict constitutional amendments limiting the growth in state and local government revenues and expenditures to a chosen metric, such as the rate of inflation or population growth rates (Joyce and Mullins, 1991; Kornhauser, 2002; Mullins, 2004; Mullins and Wallin, 2004; Stallmann, 2007).

If governments are not to be trusted to have fiscal policies that are conducive to economic growth, and tax and expenditure limits impose that fiscal discipline, a natural policy question is do TELs influence economic growth? The economic theory on the potential impact of TELs on economic growth is mixed. The Leviathan-Niskanen-Buchanan model suggests that more restrictive TELs should improve economic growth by cutting out wasteful spending and providing transparency and stability in taxing policies. Alternatively, TELs could cut investment in productive resources, which would inhibit economic growth. A small handful of studies of empirical studies have addressed this issue (McGuire and Rueben, 2006; Deller and Stallmann, 2007; Stallmann and Deller, 2010, 2011; Deller, Stallmann and Amiel, 2012). In general these studies have found no evidence that TELs have a positive influence on economic growth and limited evidence that they may impair growth. Most studies examining the link between economic growth and TELs, however, have used a dummy variable to account for the presence of a TEL; the use of dummy variables does not allow researchers to account for the large variation in the restrictiveness of TELs. This study contributes to the small but growing literature by exploring how the restrictiveness of different types of state tax and expenditure limitations influence state economic growth within a simple neoclassical growth framework using a Barrotype empirical growth model. 
Beyond these introductory comments, the study is composed of five sections. The literature of studies looking at the relation between TELs and economic growth is summarized. A simple spatial neoclassical growth framework is reviewed with attention to how TELs can influence growth. Then, a Barro-type empirical growth model is presented with a discussion of the unique indices of TEL restrictiveness used in this study. A variable parameter specification is used to test for the influence of TELs on economic growth over the range of TEL restrictiveness. Next, the empirical results are presented and discussed. The study closes with a discussion of the policy ramifications of the work.

\section{TAX AND EXPENDITURE LIMITS AND ECONOMIC GROWTH}

Given the focus of the arguments in favor of tax and expenditure limitations, it is somewhat surprising that the impact of TELs on economic performance has been largely overlooked. To our knowledge there are only a small handful of relevant studies. McGuire and Rueben (2006), one of the first to address the TEL and economic performance question, restrict their analysis to one region of the country, the impact of Colorado's TABOR in relation to the other Mountain West states. They conclude that Colorado's TABOR had little if any impact on the long-term economic growth of Colorado, measured in terms of both employment and per capita income. They observe that there may have been a short-run positive impact, but over time that positive influence disappeared. ${ }^{1}$ Deller and Stallmann (2007) look at TELs imposed on local and state governments nationwide using simple dummy variables for TELs imposed pre- and post-1987. They find that TELs imposed on local governments may have a negative impact on the growth of per capita income in the short run but that they do not appear to affect economic growth in the long run. TELs imposed on state governments, on the other hand, may have a positive impact on economic growth. As a possible explanation, they suggest that the public services that matter most to the economy are generally provided by local and not state governments.

Stallmann and Deller (2010) use a growth model with intercept dummy variables to examine the impact of the most restrictive forms of tax and expenditure limits on income growth and slope dummy variables to test for convergence among U.S. states. None of the intercept dummies are significant, suggesting that there is no evidence that TELs influence economic growth. They find that local TELs, which are mainly property tax levy limits, do not significantly affect convergence rates. Their results for state TELs suggest that states with limits imposed before 1987 experienced slower rates of income convergence while those with more recent limits experienced increased convergence. This could suggest that limits become more binding in the long term, making it difficult for the states to provide "productive infrastructure," ultimately, resulting in slower economic growth (Barro, 1991, 1997; Mofidi and Stone, 1990; Reed, 2008). In the short run, perceptions of state action to curb inefficient spending may have a positive impact on economic growth, but over time the positive effect may turn negative.

The use of simple dummy variables to capture the presence of tax and expenditure limits is the primary limitation of the aforementioned studies. As noted by Joyce and Mullins (1991) and Kioko (2011), no two states have structured TELs exactly the same, and simply dummy

\footnotetext{
${ }^{1}$ Of particular note, in November 2005, Colorado voters approved Referendum C, a ballot measure that loosened many of TABOR's restrictions. Major proponents of Referendum C were various Denver business associations who expressed concern that the inability of the state to invest in major infrastructure projects would lead to bottlenecks in the growth of the state's economy.
}

(C) Southern Regional Science Association 2013. 
variables cannot capture the complexity and diversity of TELs across the states. If one appeals to the concept of entropy from information theory (Shannon, 1948; Theil, 1967; Golan, 2002), it tells us that compressing complex ideas, like TELs, into a single dimensional metric, like a dummy variable, can lead to inferior inferences. As argued in more detail below, scaled metrics or indices, which more fully reflect the heterogeneity of TELs, can introduce more information into the modeling process. This should improve inferences regarding the impact of TELs on states.

Stallmann and Deller (2011) move beyond using a simple dummy variable to represent TELs and use an index of state TEL restrictiveness developed by Poulson (2005). Grouping states into four categories of increasing restrictiveness based on Poulson, they use parametric and non-parametric tests of sub-sample equivalency on 84 separate measures of economic performance, business vitality and development capacity. In general they find no evidence that tax and expenditure limitations imposed on state governments are associated with higher levels of economic performance. Rather, they find limited evidence that in some cases, tax and expenditure limitations hinder business climate and economic performance. Unfortunately, by grouping states into quartiles, some information on restrictiveness is lost. Second, the analysis examines one year and is cross-sectional in nature, which does not capture dynamic processes which may occur as TELs become more binding or are changed over time.

To address these shortcomings, Deller, Stallmann and Amiel (2012) construct a dynamic index of TEL restrictiveness in the spirit of Poulson (2005), and to a lesser extent the work of the Advisory Commission on Intergovernmental Relations (ACIR, 1987), Resnick (2004) and Bae and Gais (2007). The value of the annual index each year from 1969 to 2005 reflects the restrictiveness of the TEL in that year. There is one index for TELs imposed on state governments, and a second for TELs imposed on local governments. Using a panel approach Deller, Stallmann and Amiel (2012) find that more restrictive TELs imposed on state governments have a negative effect on state economic growth; additionally, TELs imposed on local governments have a weak negative impact on growth. They conclude that their results do not support the argument that the enactment of tax and expenditure limits is a mechanism to promote economic growth. The limitation to this work is that it does not distinguish between TELs that restrict either revenue or expenditure streams or both; all TELs are aggregated into one index. Studies that examine the implications of TELs on fiscal decisions and the unintended consequences of TELs on other aspects of the economy, such as public credit ratings, have revealed that results are sensitive to the focus of the TEL (e.g., Poterba and Rueben, 1999a and 1999b; Wagner, 2004; Johnson and Kriz, 2005).

This study moves the literature forward by constructing three separate TEL restrictiveness indices; one index focuses on TELs that restrict only state revenues, another on TELs that restrict only state expenditures, and a final on TELs that restrict both revenues and expenditures such as Colorado's TABOR. Using a set of three TEL restrictiveness indices, we are able to test if the focus of the TEL influences state growth patterns. Unlike Deller, Stallmann and Amiel (2012), we do not consider TELs imposed on local governments, and focus only on state government limitations.

\subsection{Theoretical Growth Framework}

A traditional neoclassical model of regional economic growth, as presented by Barro and Sala-i-Martin (1992), Nijkamp and Poot (1998), Keely and Quah (2000) and Durlauf, Johnson 
and Temple (2005), is adapted to test the research question discussed above: do tax and expenditure limitations imposed on state governments influence economic growth? In neoclassical theory, developed by Ramsey (1928), Solow (1956), Cass (1965) and Koopmans (1965), growth rates in per capita income are inversely related to the initial levels of per capita income; over time, any given set of economies that are similar in terms of preferences and technology should see a convergence in per capita income. That is to say, poorer regions should grow faster than richer ones. This central hypothesis has been tested in hundreds of studies using what is now widely referred to as a Barro-type model:

$$
\Delta \mathbf{y}_{t}=\alpha_{o}+\alpha_{1} \mathbf{y}_{t-1}+\sum_{i=1}^{m} \delta_{i} \mathbf{X}_{i, t-1}+\varepsilon
$$

$\mathrm{y}$ is per capita nominal income and $\mathrm{X}$ is a set of control variables, which for this study include tax and expenditure limitations. $\varepsilon$ is an error term such that $\varepsilon=\mathrm{u}_{\mathrm{i}}+\mathrm{v}_{\mathrm{it}}$, where $\mathrm{u}_{\mathrm{i}}$ and $\mathrm{v}_{\text {it }}$ are the stateand time-specific effects (or measurement error) respectively. In order to account for unobserved correlation between states and across time, two-way fixed effects are included in the dynamic Generalized Method of Moments estimator discussed below.

The parameter of interest is $\alpha_{1}$ (which equals $\left.\partial\left(\Delta \mathrm{y}_{\mathrm{t}}\right) / \partial_{1} \mathrm{y}_{\mathrm{t}-1}\right)$, commonly called the $\beta$ convergence parameter. The robustness of the results of the traditional neoclassical empirical growth model is at the center of a large literature (Pack, 1994; Durlauf and Quah 1999; Brock and Durlauf, 2001; Beugelsdijk, de Groot and van Schaik, 2004; Durlauf, Johnson and Temple, 2005; Brock, Durluaf and West, 2007). Despite the wide use of the neoclassical-derived, Barrotype growth model, Levine and Renelt (1992), in particular, are very critical of its use. They maintain that the rate of $\beta$-convergence is very sensitive both to model specification and the time frame that is examined. The concern over model specification has spawned a large and growing literature about model uncertainty and methods to address it (see, for example, Deller and Lledo, 2007 for a detailed discussion). We elect to retain this framework because of the simple and direct way public services (i.e., public capital) can be logically introduced, yet we acknowledge and respect its shortcomings.

Within this simple framework the question is why, if at all, tax and expenditure limitations would directly or indirectly influence growth rates? Consider the two underlying factors of production that enter into the neoclassical growth model: labor and capital. It has been widely accepted that capital is composed of two parts: private and public capital (e.g., da Silva Costa, Ellson and Martin 1987). Public capital is traditionally viewed as public infrastructure such as highways, bridges and water treatment systems among others. Indeed, the link between public capital in the form of infrastructure has been the focal point of another literature (e.g., Ratner 1983; Aschauer 1989a, 1989b, 1989c; Johnson, Deaton and Segarra 1988; Aaron 1990; Hulten and Schwab 1991; Tatom 1991a,b; Jorgenson 1991; Holtz-Eakin 1994). ${ }^{2}$ While the magnitude of the relationship between public infrastructure and economic growth remains a topic of debate, the general consensus is that investments in public infrastructure are a necessary, but not sufficient, condition for economic growth.

As noted by Bergh and Henrekson (2011), Bartik (1991, 1992) and Barro (1991), however, public capital is broader than simple infrastructure and includes "productive" public

${ }^{2}$ See Munnell (1992), Romp and de Haan (2007), Straub (2008) and de al Fuente (2010) for reviews of this literature. 
services such as police and fire protection and environmental production. Some research suggests that as incomes increase, services that add to the quality of life, such as state parks and recreational services, have a positive impact on growth (Deller, et al., 2001). Public investments can also impact growth through the productivity of labor. Human capital theory, rooted in the works of Schultz (1961), Becker (1962, 1985), and Mincer (1962), builds on the neoclassical model of perfectly competitive labor markets and argues that human capital investments influence the growth process by increasing the productive capacity of the labor force (Clark 1983; Becker 1985; Beaulieu and Mulkey 1995; Goetz and Hu 1996). Examples of human capital investments include schooling, on the job training and health care amongst others. Such investment makes a worker more productive by augmenting skills, knowledge, health, or other productive attributes. The improvements in human capital can have utility to a variety of firms or be firm specific, having applications only to the particular enterprises involved. ${ }^{3}$

Tax and expenditure limitations (TELs), by placing a cap on either revenues or expenditures or both, may lead to under-investment in productive public and/or human capital and result in slower economic growth rates. The counter argument is that rate of investment is currently too high because of Leviathan-Niskanen-Buchanan type pressures. In addition, the mix of public investments may be misdirected into unproductive public services or into a less than optimal mix. These mis-investments divert resources away from more productive private capital investments. Proponents of TELs maintain that such limits will restrict public resources and move them to the most productive investments.

\subsection{Empirical Framework}

To address the sensitivity of the rate of $\beta$-convergence to the restrictiveness of tax and expenditure limitations we employ a variable parameter specification (Deller et al, 2003), and allow both the intercept $\left(\alpha_{0}\right)$ and growth parameter $\left(\alpha_{1}\right)$ to be influenced by the restrictiveness of the state TEL. Specifically, we allow the intercept to vary by the TEL measure.

$$
\alpha_{\mathrm{o}}=\beta_{0}+\beta_{1} \boldsymbol{T E} \boldsymbol{L}
$$

as well as the growth parameter

$$
\alpha_{1}=\gamma_{0}+\gamma_{1} \boldsymbol{T E L} .
$$

where TEL is a measure of the restrictiveness and structure of the TEL (described in further detail below). Substituting eqs. ( $2 a$ and $2 b$ ) into the basic Barro-type regression equation (eq.(1) yields the model to be estimated:

$$
\Delta \mathbf{y}_{t}=\beta_{o}+\beta_{1} \mathbf{T E L}+\gamma_{0} \mathbf{y}_{t-1}+\gamma_{1} \mathbf{T E L}\left[\mathbf{y}_{t-1}+\sum_{i=1}^{m} \delta_{i} \mathbf{X}_{i, t-1}+\varepsilon\right.
$$

By design, the TEL measure, described below, can influence the convergence rate

$$
\partial \Delta \mathbf{y}_{\mathbf{t}} / \partial \mathbf{y}_{\mathbf{t}-1}=\gamma_{0}+\gamma_{1} \boldsymbol{T E} \boldsymbol{L},
$$

as well as the overall rate of growth:

$$
\partial \Delta \mathbf{y}_{\mathbf{t}} / \partial \boldsymbol{T E L}=\beta_{1}+\gamma_{1} \mathbf{y}_{\mathbf{t}-1} \text {. }
$$

\footnotetext{
${ }^{3}$ See Wilson and Briscoe (2004) for just one of the many reviews of the human capital and economic growth literature.

(C) Southern Regional Science Association 2013.
} 
Based on the theoretical arguments, there are two competing interpretations of how TELs could influence economic growth. Because TELs place an upper bound on the investment and replacement of public capital, state level TELs could dampen economic growth. This can lead to underinvestment in productive public goods and services which in turn reduces private rates of return to capital and labor. Due to public underinvestment, states with more restrictive TELs may grow more slowly. In this specification, if $\partial \Delta \mathbf{y}_{\mathbf{t}} / \partial \boldsymbol{T E} \boldsymbol{L}<0$, more restrictive TELs are associated with slower growth rates.

On the other hand, if $\partial \Delta \mathbf{y}_{\mathrm{t}} / \partial \boldsymbol{T} \boldsymbol{E} \boldsymbol{L}>0$, more restrictive TELs are associated with faster growth rates and the Leviathan-Niskanen-Buchanan model is supported; government is inherently inefficient and cannot be trusted to implement effective and efficient fiscal policies. If TELs impose fiscal discipline and result in a more efficient use of public resources, the theory predicts that the flow of private capital and labor into the state is more likely to follow an efficient trajectory. These two effects together should provide a positive influence on economic growth.

How TEL restrictiveness influences the rate of $\beta$-convergence $\left(\partial \Delta \mathbf{y}_{\mathrm{t}} / \partial \mathbf{y}_{\mathrm{t}-1}\right)$ is also clear from the competing theoretical perspectives. If TELs place a cap on investment and replacement of public capital, goods or services, then the convergence parameter will be reduced in magnitude, indicating that more restrictive TELs hinder the ability of states to grow at faster rates by preventing investment in public infrastructure and capital. In other words, markets are not able to adjust in a manner consistent with competitive markets. If the TELs create a strong incentive to use limited public resources in a more efficient manner, then the speed of convergence should accelerate. Alternatively, within the context of an individual state with high per capita personal income a more restrictive TEL may result in slower growth.

Our control variables include: ${ }^{4}$

- $\quad$ Per Capita Income from Income Maintenance Programs

- $\quad$ Per Capita Income from Unemployment Programs

- $\quad$ Per Capita Income from Retirement Sources

- $\quad$ Percentage Employment in Durable Manufacturing

- $\quad$ Percentage Employment in Non-Durable Manufacturing

- $\quad$ Percentage Employment in Finance and Insurance

- $\quad$ Percentage Employment in Professional, Scientific

- $\quad$ Percentage Employment in State Government.

Per capita income from income maintenance programs is intended to control for not only levels of poverty, but also "unproductive" government expenditures. Per capita income from unemployment programs is a proxy of state-specific business cycles and again what might be deemed "unproductive." Per capita income from retirement sources includes transfers from the

\footnotetext{
${ }^{4}$ All of the data, other than the TEL index, are available from the US Census Bureau, Bureau of Economic Analysis, Regional Economic Information System and the Bureau of Labor Statistics.
}

(C) Southern Regional Science Association 2013. 
government for retirement, disability and medical care among others and is aimed to capture the aging population and labor force. The remaining variables, percentage of employment across different sectors, control for the economic structure of the state. In addition, employment in professional and scientific areas is a proxy for technology.

Given the panel nature of the data, the potential estimation methods range from pooled OLS, to fixed and random effects and generalized method of moments (GMM). Each has its strengths and weaknesses as well as advocates and dissenters (Abreu, de Groot and Florax, 2005; Partridge, 2005). The fixed effects model (FE) allows for individual effects that are time invariant like regional climate or geography, which minimizes omitted variable bias, but the estimator is inconsistent in the presence of endogeneity. Durlauf, Johnson and Temple (2005) note that the standard random effects model requires that region-specific effects be distributed independently of the explanatory variables, which is clearly violated for a dynamic panel as traditionally developed in growth theory. This latter observation is the reason that FE models have dominated growth studies that employ panel data. In addition, the random effects (RE) model is most appropriate when the data sample is a random draw from a known population. In our case, we have data on the entire population, which in this case includes all fifty of the United States.

A serious problem with the empirical growth literature is the failure to adequately address the issue of endogeneity of the control variables. From our set of control variables, it is clear that nearly all could be a direct function of economic growth. To address the endogeneity issue, Arellano and Bond (1991) and Caselli, Esquivel and Lefort (1996) use a generalized method of moments (GMM) estimator. The dymanic panel GMM generally uses either the lagged differences of the dependent variable (e.g. $\mathbf{y}_{\mathrm{i}, \mathrm{t}-2}-\mathbf{y}_{\mathrm{i}, \mathrm{t}-3}$ ) or the lagged levels of the dependent variable (e.g. $\mathbf{y}_{\mathrm{i}, \mathrm{t}-2}$ or $\mathbf{y}_{\mathrm{i}, \mathrm{t}-3}$ ) as instruments for $\mathbf{y}_{\mathrm{t}-1}$ ( Greene 2012). This minimizes problems of endogeneity. Sometimes referred to as an autoregressive dynamic panel estimator, the GMM estimator is useful in dealing with autoregressive data. As noted by Minoiu and Reddy (2010) the GMM approach has supplanted the more traditional fixed and random effects estimators to model economic growth (e.g., Deller, Stallmann and Amiel 2012). ${ }^{5}$

A consistent and efficient estimate of the $\beta, \gamma$ and $\delta$ from eq.(3) (let $\lambda \equiv \beta, \lambda, \delta$ ) can be obtained by minimizing the GMM criterion function $N(\mathbf{y}-\mathbf{X} \lambda)^{\prime} \mathbf{Z}\left(\mathbf{V}_{\mathbf{N}}\right)^{-1} \mathbf{Z}^{\prime}(\mathbf{y}-\mathbf{X} \lambda)$ where $\mathrm{V}_{\mathrm{N}}$ is a consistent estimate of $\mathbf{V} \equiv \mathrm{E}\left(\mathbf{Z}^{\prime} \boldsymbol{\varepsilon} \boldsymbol{\varepsilon}^{\prime} \mathbf{Z}\right), \mathbf{Z}$ is a set of instrumental variables, $\boldsymbol{\varepsilon}$ is the classical regression error term, and $\mathbf{N}$ is the number of cross-sectional units or states. The solution to the minimization problem leads to the GMM estimator

$$
\hat{\lambda}_{G M M} \equiv\left[\mathbf{X}^{\prime} \mathbf{Z} \mathbf{V}_{N}^{-1} \mathbf{Z}^{\prime} \mathbf{X}\right]^{(-1)} \mathbf{X}^{\prime} \mathbf{Z} \mathbf{V}_{N}^{-1} \mathbf{Z}^{\prime} \mathbf{y}
$$

For this study, the instruments $(Z)$ include the dependent variable, annual growth in per capita income lagged five years $\left(\Delta \mathbf{y}_{\mathrm{i}, t-5}\right)$, and the exogenous variables include percentage of the population under age 18 as well as the percentage over age $65 .^{6}$

\footnotetext{
${ }^{5}$ While there is some concern that the dynamic panel GMM model might be misspecified if the spatial interdependence between states is ignored (Arbia et al., 2008), dynamic spatial panel GMM models are still in the developmental stages. In addition, the use of state fixed effects, which are presented in the dynamic GMM panel estimator, may include some of the interdependence.

${ }^{6}$ The lagged dependent variable specification can be expressed in a general form as: $\Delta \boldsymbol{Y}_{i t}=\sum_{l=1}^{5} \varphi_{l} \Delta \boldsymbol{Y}_{i(t-l)}+$ $\sum_{k}^{K} \beta_{k} \boldsymbol{X}_{i t k}+e_{i t}$. Here $\sum_{l=1}^{5} \varphi_{l} \Delta \boldsymbol{Y}_{i(t-l)}$ reflects the five year lagged instruments.
} 
The next step is to construct an index to capture the restrictiveness of tax and expenditure limitations. As noted above Joyce and Mullins (1991) delineate six broad types of TELs and a given state may have one or a combination of several of these characteristics. The least restrictive are full disclosure or "truth-in-taxation" rules, which generally require some public discussions and a specific legislative vote in open meetings prior to enactment of a tax rate increase. Similarly, a limit that focuses on a particular revenue source, such as the property tax, may not limit officials from increasing other sources such as sales taxes and/or fees and charges. The most restrictive TELs limit the amount or the percentage by which revenues and/or expenditures can increase from the previous year (Resnick, 2004). If a state cuts its budget in a downturn, as the economy rebounds the state remains on a lower trend line based on the low spending or revenue in the recession year. Most binding are these latter types of TELs that also are constitutional rather than statutory because statutes can be changed more easily (Poulson, 2005; Resnick, 2004; Poterba and Reuben, 1999b).

As noted above most of the studies that have examined the impact of TELs on economic growth and/or economic performance have used simple dummy variables to capture the presence of a TEL (e.g., McGuire and Rueben, 2006; Deller and Stallmann, 2007; Stallmann and Deller 2010). As argued in both Stallmann and Deller (2011) and Deller, Stallmann and Amiel (2012), simple dummy variables cannot capture the heterogeneity of TELs sufficiently to provide adequate insights into the impact of TELs on the economy. From a purely theoretical perspective, the concept of entropy from information theory points out that compressing complex information, such as TELs, into a single dummy variable provides a minimum amount of information (Shannon 1948; Theil 1967; Golan, 2002). Compare, for example, the information contained in a fair single two-sided coin and a fair six-sided dice. From information theory, because there are more potential outcomes from the six sided dice, there is more information. Staying with the coin and dice analogy, if there are six states with six different TELs and that information is compressed into a yes/no dummy variable, by definition information is lost.

Thus, we build on Deller, Stallmann and Amiel (2012), who in turn built on the work of the Advisory Commission on Intergovernmental Relations (ACIR, 1987), Resnick (2004), Wagner (2004), Poulson (2005), and construct three indices of TEL restrictiveness. ${ }^{7}$ Deller, Stallmann and Amiel (2012) construct a TEL restrictiveness index based on six dimensions of TELs: (1) the breadth of coverage of the TEL; (2) if the TEL is statutory or constitutional; (3) growth restrictions; (4) method of TEL approval; (5) override provisions; and (6) exemptions. Each state received points for each of six dimensions every year. Higher point values in each category correspond to stricter limitations. Additionally, each exemption or override provision to the TEL is assigned a value of negative one, because they make a given TEL less restrictive. As with previous restrictiveness measures, the rankings on each dimension are ordinal and the rankings are summed. Because there is no way to determine how much more restrictive one type of limit is than another, the index does not reflect magnitudes; we can only establish and compare the relative intensity of each limit. As a consequence, all of the indices created to date, including these, are ordinal in nature. We modify the Deller, Stallmann and Amiel (2012) index in two distinct ways. First, we use the first category, breadth of coverage, to construct a set of indices by type of state TEL: (1) only revenue limits; (2) only expenditure limits; and (3) both

\footnotetext{
${ }^{7}$ The National Conference on State Legislatures (NCSL) has an excellent overview of the TELs in each state, their dates of adoption and the growth restrictions on each. See Waisanen at: http://www.ncsl.org/issues-research/budget/state-tax-andexpenditure-limits-2010.aspx
}

(C) Southern Regional Science Association 2013. 
revenue and expenditure limits. Secondly, we simplified the other categories so the point values assigned are slightly different from the original index. See Appendix Table A for more details about the six categories and the point values assigned in each. The highest score for the revenue TEL is 20 , for the expenditure TEL is 22 and for the TEL that restricts both revenues and expenditures is 18 .

In 1990, the beginning of the time period for this study, 24 states had a TEL; six had a revenue TEL, fourteen had an expenditure TEL and four had both a revenue and expenditure TEL. By 2009, 29 states had some type of TEL; six states had a revenue based TEL, eighteen states had an expenditure based TEL, and five states had both an expenditure and revenue based TEL. Twenty-two states had an expenditure TEL at some time during the study period. Nine states had a revenue TEL at some time during the study period. Nine states also had a TEL with limitations on both the revenue and expenditure at some time during the study period. A state received a score only for the type of TEL in the year in which it was in effect. It received scores of zeros on the other TELs for that year. For example, Washington State had no limit before 1993, when it implemented both an expenditure and a revenue limit. In 2000, the limit was changed to an expenditure limit only. In addition, some states made their TEL more or less restrictive over the time period. Fourteen states did not have any type of state TEL at any time during the study period and received a score of zero for each type of TEL for every year. Among the thirty-six states with a TEL at some point during the time period, it is important to note that five states changed the type of TEL during the study period so that at one time they fell into one category and later fell into another category.

\section{EMPIRICAL RESULTS}

We estimate two versions of the variable parameter growth model (Table 1). Model A uses an aggregation of the three TEL restrictive indices, where the TEL score for the state was used without reference to its type. This "aggregate TEL index" would be conceptually comparable to the metric used in Deller, Stallmann and Amiel (2012). Model B is the fully specified model and includes the three individual TEL restrictiveness indices. The results are presented into two parts; the first is a summary discussion of the control variables, and the second focuses on the TEL indices and their relationship to growth and convergence rates.

All of the control variables are statistically significant and the signs are consistent across the two models. As expected, both higher levels of per capita income-maintenance payments and per capita income from unemployment programs are associated with lower per capita income growth rates. Higher levels of per capita income from retirement sources also are associated with higher growth rates in per capita income. This result may be driven by retirement migration to warmer climates which in turn may be contributing to growth in those regions while the states that the retirees leave necessarily have lower income from these sources and lower economic growth due to the loss of this income.

Higher dependency on both durable and non-durable manufacturing employment has a dampening impact on per capita income growth. This may be partially driven by the movement of manufacturing overseas, the growth of smaller, more flexible manufacturing that is not unionized and also by the decrease in unionization in general. It may also indicate a state whose economic structure is not evolving. A higher dependency on the finance and insurance sector increases per capita income growth. A higher dependency on professional and scientific sectors 
Table 1: Growth In Per Capita Income 1990-2010

\begin{tabular}{|c|c|c|}
\hline & Model A & Model B \\
\hline Constant & $\begin{array}{r}-0.00168 \\
(0.9668)\end{array}$ & $\begin{array}{l}0.00120 \\
(0.9755)\end{array}$ \\
\hline Per Capita Income & $\begin{array}{r}-0.00136 \\
(0.0001)\end{array}$ & $\begin{array}{r}-0.00137 \\
(0.0001)\end{array}$ \\
\hline Per Capita Income from Income Maintenance Programs & $\begin{array}{r}-0.03474 \\
(0.0001)\end{array}$ & $\begin{array}{r}-0.03587 \\
(0.0001)\end{array}$ \\
\hline Per Capita Income from Unemployment Programs & $\begin{array}{r}-0.02233 \\
(0.0001)\end{array}$ & $\begin{array}{r}-0.02368 \\
(0.0001)\end{array}$ \\
\hline Per Capita Income from Retirement Sources & $\begin{array}{c}0.00966 \\
(0.0001)\end{array}$ & $\begin{array}{l}0.01031 \\
(0.0001)\end{array}$ \\
\hline Percentage Employment in Durable Manufacturing & $\begin{array}{r}-0.67839 \\
(0.0001)\end{array}$ & $\begin{array}{c}-0.69452 \\
(0.0006)\end{array}$ \\
\hline Percentage Employment in Non-Durable Manufacturing & $\begin{array}{r}-1.10326 \\
(0.0006)\end{array}$ & $\begin{array}{c}-0.96859 \\
(0.0084)\end{array}$ \\
\hline Percentage Employment in Finance and Insurance & $\begin{array}{l}2.09211 \\
(0.0001)\end{array}$ & $\begin{array}{l}2.29084 \\
(0.0001)\end{array}$ \\
\hline Percentage Employment in Professional, Scientific & $\begin{array}{c}5.52198 \\
(0.0001)\end{array}$ & $\begin{array}{r}5.00733 \\
(0.0001)\end{array}$ \\
\hline Percentage Employment in State Government & $\begin{array}{r}-2.28000 \\
(0.0001)\end{array}$ & $\begin{array}{r}-2.25131 \\
(0.0001)\end{array}$ \\
\hline Aggregate TEL & $\begin{array}{r}1.04210 \\
(0.0001)\end{array}$ & - \\
\hline (Aggregate TEL)*(Per Capita Income) & $\begin{array}{r}-0.00003 \\
(0.0001)\end{array}$ & - \\
\hline Revenue TEL & - & $\begin{array}{l}1.05232 \\
(0.0003)\end{array}$ \\
\hline (Revenue TEL)*(Per Capita Income) & - & $\begin{array}{r}-0.00004 \\
(0.0031)\end{array}$ \\
\hline Expenditure TEL & - & $\begin{array}{l}1.09649 \\
(0.0001)\end{array}$ \\
\hline (Expenditure TEL)*(Per Capita Income) & - & $\begin{array}{c}-0.00003 \\
(0.0008)\end{array}$ \\
\hline Revenue and Expenditure TEL & - & $\begin{array}{l}1.27700 \\
(0.0001)\end{array}$ \\
\hline (Revenue and Expenditure TEL)*(Per Capita Income) & - & $\begin{array}{r}-0.00004 \\
(0.0002) \\
\end{array}$ \\
\hline
\end{tabular}

p-values in parentheses. All right-hand side variables lagged one year.

(C) Southern Regional Science Association 2013. 
for employment also is associated with faster rates of per capita income growth. This result is consistent with the role of technology in economic growth and is supportive of an endogenous growth theoretic framework.

The final control variable, percentage of employment in state government, could be interpreted as a direct measure of the broader question; is the size of government an impairment to economic growth? The coefficient is negative and statistically significant lending evidence to this hypothesis, particularly for state governments. Our specification, however, does not address the more subtle argument that the key to the issue is that growth in the size of government should be smaller than the growth in the overall economy (Bergh and Henrekson, 2011).

For the central hypothesis of the study we find that the individual coefficients associated with the TEL indices of restrictiveness are statistically significant at or above the standard threshold of 95 percent confidence. Because of the variable parameter specification of the model, the individual parameters, including the parameter on lagged per capita income, the traditional $\beta$ convergence parameter, have no direct interpretation. To test the significance of the joint parameters of eqs. ( $4 \mathrm{a}$ and $4 \mathrm{~b}$ ), we estimated a series of Wald tests, presented in Table 2, to determine if the joint parameters are statistically different from zero. In each case, the Wald statistic of the joint parameters, evaluated at the mean of the TEL index or lagged income respectively, are statically significant above the 95 percent threshold, strongly suggesting that TEL restrictiveness has an influence on state per capita income growth over the 1990 to 2010 period. In order to examine the impact of TELs on state growth and convergence, we graphed the growth rate and $\beta$-convergence over the span of TEL index values and levels of lagged per capita income. These are shown Figures 1 and 2 below.

It is important to recall that each of the TEL indices are ordinal and the values of the indices cannot be directly compared, that is, where the lines intersect, the vertical axis cannot be interpreted as one magnitude being larger than the other; instead, whether they are above or below zero is the focus. At best we can look at the general trends between the indices as well as examine the slope of the convergence rate. Thus, when examining the impact of TELs on convergence, we need to explore each type of TEL separately.

Table 2: Variable Parameter Wald Test

\begin{tabular}{lcccc}
\hline \hline & Revenue & Expenditure & Rev\&Exp & Aggregate \\
& TEL & TEL & TEL & TEL \\
\hline$\partial \Delta \mathrm{Y}_{\mathrm{t}} / \partial \mathrm{Y}_{\mathrm{t}-1}=\gamma_{0}+\gamma_{1} T E L$ & 14.27 & 13.93 & 15.04 & 15.53 \\
& $(0.0002)$ & $(0.0002)$ & $(0.0001)$ & $(0.0001)$ \\
& & & & \\
$\partial \Delta \mathrm{Y}_{\mathrm{t}} / \partial T E L=\beta_{1}+\gamma_{1} \mathrm{Y}_{\mathrm{t}-1}$ & 13.08 & 18.05 & 28.65 & 59.00 \\
& $(0.0003)$ & $(0.0001)$ & $(0.0001)$ & $(0.0001)$ \\
\hline \hline
\end{tabular}

Note: $p$-values in parentheses.

(c) Southern Regional Science Association 2013. 
Figure 1: Influence of TELs on Convergence Rate

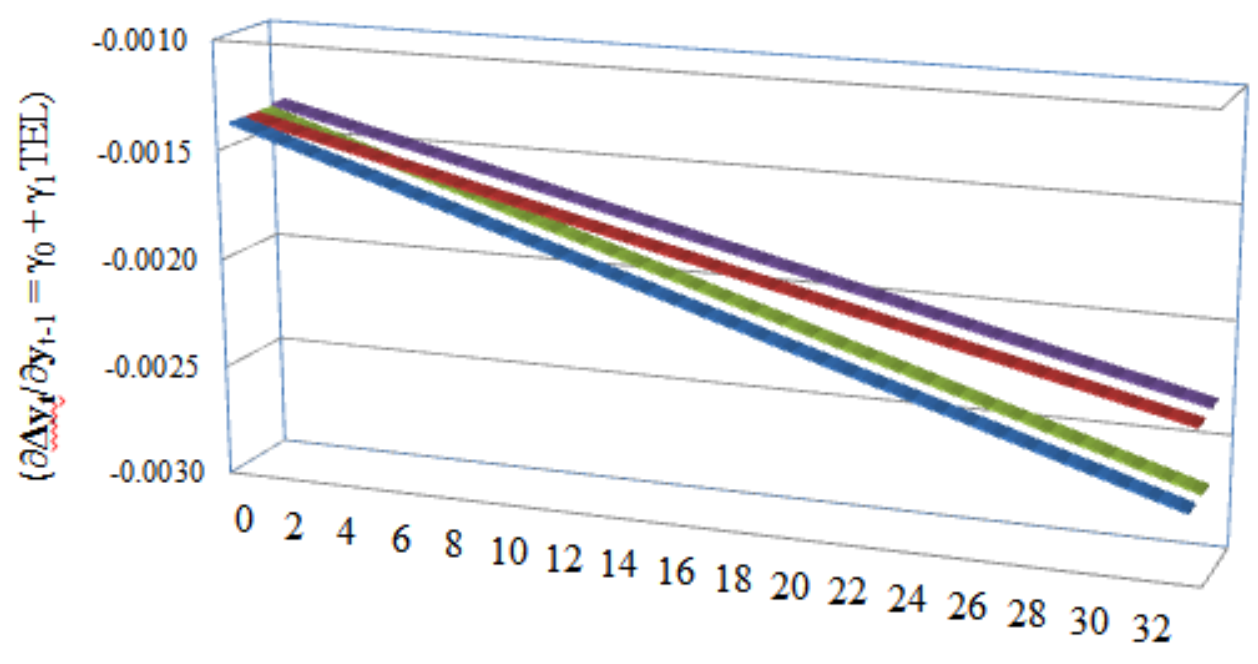

TEL Restrictiveness Indices

$\because$ Revenue TEL $\quad$ Expenditure TEL $\square$ Rev\&Exp TEL $\quad$ Aggregate TEL

Consider first how TEL restrictiveness influences $\beta$ convergence, or $\partial \Delta \mathbf{y}_{\mathrm{t}} / \partial \mathbf{y}_{\mathrm{t}-1}=\gamma_{0}+$ $\gamma_{1} \boldsymbol{T E L}$. Model A gives an annual index value to each state based on the restrictiveness of the TEL in the state without taking the type of the TEL into account. $\beta$ convergence is given by $\partial \Delta \mathbf{y}_{\mathrm{t}} / \partial \mathbf{y}_{\mathrm{t}-1}=\gamma_{0}+\gamma_{1} \boldsymbol{A g g} \boldsymbol{T E} \boldsymbol{L}$. Model B, on the other hand, uses three separate TEL indices based on the type of the TEL so that it is possible to investigate how each specific type of TEL influences convergence and economic growth. The $\beta$ convergence is given by $\partial \Delta \mathbf{y}_{\mathrm{t}} / \partial \mathbf{y}_{\mathrm{t}-1}=\gamma_{0}+$ $\gamma_{1} \operatorname{RevTEL}+\gamma_{2}$ ExpTEL $+\gamma_{2}$ BothTEL. In the absence of a TEL, the $\beta$ convergence is given by $\partial \Delta \mathbf{y}_{\mathrm{t}} / \partial \mathbf{y}_{\mathrm{t}-1}=\gamma_{0}$. Note that by construction each state can only have one type of TEL or none in any given year. Thus, depending on the type of TEL, the $\beta$ convergence reduces down to $\partial \Delta \mathbf{y}_{\mathrm{t}} / \partial \mathbf{y}_{\mathrm{t}-1}=\gamma_{0}+\gamma_{1}$ TEL where TEL can either be a revenue TEL, expenditure TEL or a TEL that limits both revenues and expenditures. If $\partial \Delta \mathbf{y}_{\mathrm{t}} / \partial \mathbf{y}_{\mathrm{t}-1}<0$ over the range of TELs, convergence is confirmed, but if $\partial \Delta \mathbf{y}_{\mathrm{t}} / \partial \mathbf{y}_{\mathrm{t}-1}>0$ then lower income states are growing more slowly than higher income states, and we see divergence. Note that the convergence rate is a function of the TEL.

The value of $\partial \Delta \mathbf{y}_{\mathrm{t}} / \partial \mathbf{y}_{\mathrm{t}-1}$ over the range of the TEL restrictive indices is shown in Figure 1.Two observations warrant discussion. First, for all three types of TELs, $\partial \Delta \mathbf{y}_{\mathrm{t}} / \partial \mathbf{y}_{\mathrm{t}-1}$ is negative over the range of TEL index values. This indicates that convergence is confirmed. Secondly, across the range, as TEL restrictiveness increases, the rate of $\beta$ convergence speeds up; that is to say that as the TEL value increases, the derivative becomes more negative (the trend lines slope downward). This is true regardless of the type of TEL and suggests that TELs speed up the convergence rate between low and high income states.

The direct influence of TEL restrictiveness on economic growth is captured by $\partial \boldsymbol{\Delta} \mathbf{y}_{\mathrm{t}} / \partial \boldsymbol{T E} \boldsymbol{L}=\beta_{1}+\gamma_{1} \mathbf{y}_{\mathrm{t}-1}$. Similar to the discussion above, Model A gives an annual index value to each state based on the restrictiveness of the TEL in the state without taking the type of the 
Figure 2: Direct Influence of TELs on Economic Growth

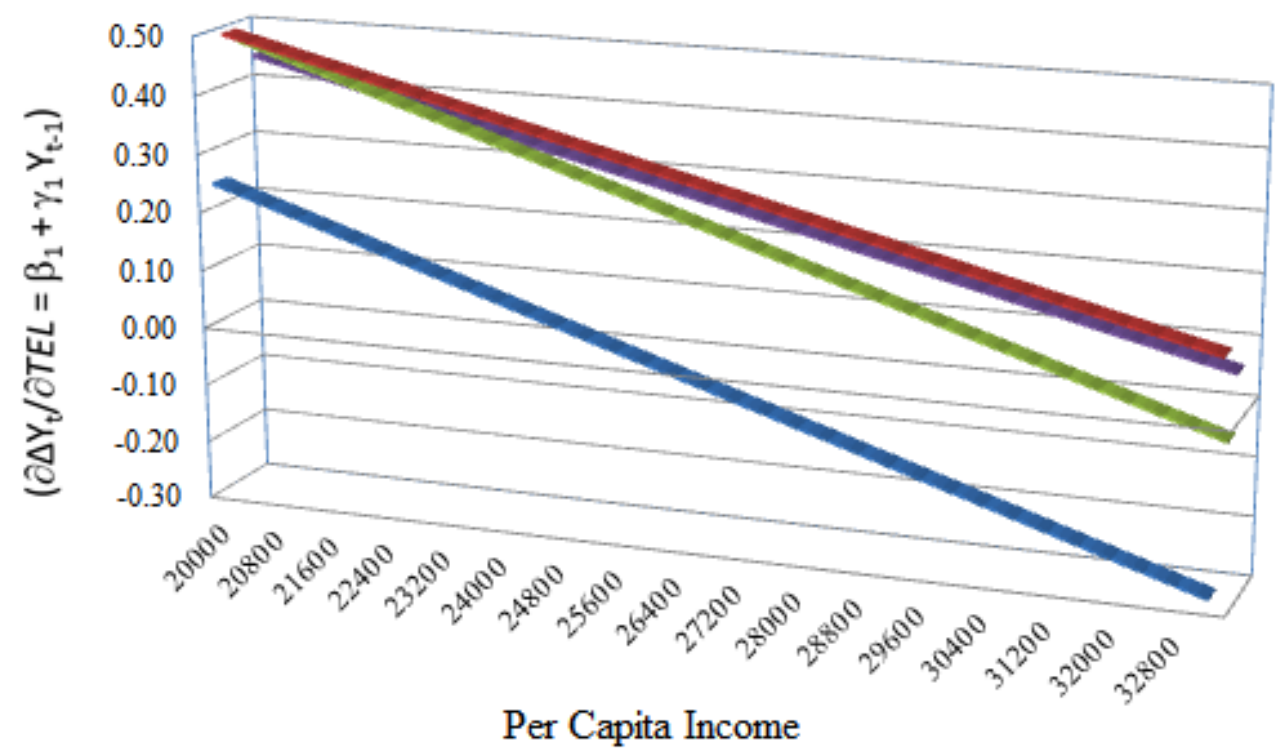

$\square$ Revenue TEL $\boxminus$ Expenditure TEL $\quad$ Rev\&ExpTEL $\quad$ Aggregate TEL

TEL into account. The growth rate is given by given by $\partial \boldsymbol{\Delta} \mathbf{y}_{\mathrm{t}} / \partial \boldsymbol{T E} \boldsymbol{L}=\beta_{1}+\gamma_{1} \mathbf{y}_{\mathrm{t}-1}$. Model $\mathrm{B}$, on the other hand, employs the three separate TEL indices based on the type of the TEL so that it is possible to investigate how each specific type of TEL influences economic growth. Taking the derivative with respect to each type of TEL, gives the ability to examine how each type of TEL impacts the growth rate. If $\partial \Delta \mathbf{y}_{\mathrm{t}} / \partial \boldsymbol{T E} \boldsymbol{L}>0$, then more restrictive TELs are associated with faster growth rates and is consistent with the Leviathan-Niskanen-Buchanan model. If, on the other hand, $\partial \boldsymbol{\Delta} \mathbf{y}_{\mathrm{t}} / \partial \boldsymbol{T E} \boldsymbol{L}<0$, then more restrictive TELs are associated with slower growth rates. This is consistent with the hypothesis that TELs place constraints on governments and results in an inefficient supply of public services.

Mapping the value of $\partial \Delta \mathbf{y}_{\mathbf{t}} / \partial \boldsymbol{T E} \boldsymbol{L}$ over the range of per capita income $(\mathbf{y})$ is provided in Figure 2. As expected, the direct influence of restrictiveness for all types of TELs on per capita income growth varies over levels of lagged per capita income, as well as by the type of TEL. Again, revenue-focused TELs have the widest variation across income levels, while the expenditure and aggregate TELs have the lowest levels of variation across income levels. The growth rate for revenue-only TELs changes from being positive for lower-middle income states to negative for upper income states. For lower-middle income states $\partial \Delta \mathbf{y}_{\mathbf{t}} / \partial \boldsymbol{T E} \boldsymbol{L}>0$, implying more restrictive TELs are associated with faster growth rates. On the other hand, at higher levels of income $\partial \Delta \mathbf{y}_{\mathrm{t}} / \partial \boldsymbol{T E L}<0$, signifying that more restrictive revenue TELs are associated with slower growth rates in higher income states. The shift of the impact from positive for low income states to negative for high income states is of particular interest.

Revenue-based TELs that keep taxes lower may be beneficial for low income states because it increases families' take-home pay. In high income states restricted revenues mean that the state cannot afford to provide larger quantities, wider varieties or higher quality public goods, which higher income citizens prefer; this may affect movement into the state. In addition, the 
growth rate with revenue TELs declines more rapidly as income increases relative to the other types of TELs. This suggests that in high income states, an expenditure TEL is preferable to a revenue based TEL because its impact on growth declines less rapidly as incomes increase.

A slightly different trend can be seen for the expenditure-only TELs and the TELs that restrict both revenues and expenditures. For both of these types of limits, the growth rate is generally positive across the entire income range; however, the negative slope of the line demonstrates that growth rates are slower for the upper income levels than they are for the lowermiddle income states. For the expenditure-based TEL, one explanation for the declining growth rate as incomes increase could be that low income coupled with more restrictive TELs forces state governments to devote their limited expenditures to the more productive public services, which contribute to economic growth. As incomes rise, however, citizens start demanding public goods that can be considered "luxury" public goods. For example, as incomes increase the demand for services such as state parks and recreational facilities not only increases but becomes expected. Or citizens or interest groups may demand more or higher quality "productive" public goods.

Three general conclusions can be drawn from these results. First, within the context of a Barro-type empirical growth model, tax and expenditure limitations can influence state growth in per capita income. Second, the relationship between TELs and economic growth varies by TEL restrictiveness as well as type of TEL. Within the context of our analysis, more restrictive TELs can speed the rate of $\beta$ convergence, that is, lower income states may grow more rapidly than higher income states. Third, the influence of TELs on growth varies over state income ranges. For poorer states more restrictive TELs may force fiscal discipline creating a more conducive environment for economic growth. But for higher income states, more restrictive TELs could hinder the provision of what might be viewed as "luxury" or "non-essential" public services that are expected in higher income states. This hindrance may place constraints on economic growth for richer states. These results suggest that some of the inconsistent results in the previous research may be due to lack of control for type of TEL and for the income dynamics of the state.

\section{CONCLUSION}

The role of government, in particular tax and expenditure policies, in economic growth is at the heart of a long and rich literature. This study adds to the small but growing part of the larger literature by examining the impact of tax and expenditure limitations (TELs) on economic growth. Using a generalized method of moments (GMM) approach we estimate a Barro-type growth model with three separate restrictiveness indices of tax and expenditure limitations imposed on state governments.

We find that more restrictive TELs tend to be associated with faster rates of convergence and overall higher rates of growth for lower income states. But as income increases, the positive impact of TEL restrictiveness on overall growth declines, and for very high income levels more restrictive TELs have either very little impact or a negative impact on growth.

It was not possible to directly investigate the mechanism by which TELs differentially influence growth in low and high income states in this paper; future research could include a closer investigation into how TELs impact productive and non-productive spending by states. However, we hypothesize that in lower income states with restrictive TELs, state governments must use their more limited resources to provide the more productive public goods that are 
necessary for economic growth. In other words, TELs can impose some level of fiscal discipline that has a positive impact on the economy. But as incomes grow, the demand for higher level goods and services, such as recreational services or higher levels of spending on education, also grows, and restrictive TELs may prevent the required investments placing downward pressure on growth.

The majority of past studies used a dummy variable for the presence or absence of a TEL. We are able to show, however, that it is important to take the heterogeneity of TELs into account. The restrictiveness of the TEL influences the rate of convergence; TELs speed up the rate of convergence and TELs that restrict revenues generally have a larger impact on convergence than TELs that restrict expenditures. Similarly, policy decision makers must be concerned with the per capita state income. A TEL may enhance economic growth in a low income state, but the opposite result could occur in a high income state.

TELs are heterogeneous as are state economies. This study demonstrates that it is difficult to make generalizations about TELs. Policy makers need to consider the specific attributes of their state as well as the type and restrictiveness of a TEL, and the implications of the interaction between income and TELs on economic growth, before deciding to implement a TEL or modify a TEL currently in place.

\section{REFERENCES}

Aaron, Henry J. (1990) "Discussion of 'Why is infrastructure important?'," in Alicia H. Munnell (ed.), Is There a Shortfall in Public Capital Investment? Conference Series No. 34, Federal Reserve Bank of Boston, June, pp. 51-63.

Abreu, Marie, Henry L.F. de Groot, and Raymond J.G.M. Florax. (2005) "A Meta-Analysis of $\beta$ Convergence: The Legendary 2\%," Journal of Economic Surveys, 19, 389-420.

Advisory Commission on Intergovernmental Relations (ACIR). (1987) Fiscal Discipline in the Federal System: National Reform and the Experience of the States. A-107. Washington, DC.

Arellano, Manuel and Stephen R. Bond. (1991) "Some Tests of Specification for Panel Data: Monte Carlo Evidence and an Application to Employment Equations," Review of Economic Studies, 58, 277-297.

Arbia, Giuseppe, Julie Le Gallo, and Gianfranco Piras. (2008) "Does Evidence on Regional Economic Convergence Depend on the Estimation Strategy? Outcomes from Analysis of a Set of NUTS2 EU Regions," Spatial Economic Analysis, 3, 209-224.

Ashbee, Edward. (2011) "Bewitched-The Tea Party Movement: Ideas, Interest and Institutions," Political Quarterly, 82, 157-164.

Aschauer, David A. (1989a) "Is Public Expenditure Productive?," Journal of Monetary Economics, 23, 177-200.

. (1989b) "Public Investment and Productivity Growth in the Group of Seven," Economic Perspectives, 13(5), 17-25.

. (1989c) "Does Public Capital Crowd Out Private Capital?," Journal of Monetary Economicl, 24, 171-188.

(C) Southern Regional Science Association 2013. 
Bae, Suho and Thomas Gais. (2007) "The Effects of State-Level Tax and Expenditure Limitations on Revenues and Expenditures," Rockefeller Institute Policy Brief, State University of New York at Albany, May 21.

Barro, Robert J. (1991) "Economic Growth in a Cross Section of Countries," Quarterly Journal of Economics, 106, 407-443. . (1997) Determinants of Economic Growth, Cambridge: MIT Press.

Barro, Robert J. and Xavier Sala-i-Martin. (1992) "Convergence," Journal of Political Economy. $100,223-251$.

Bartik, Timothy. (1991) Who Benefits from State and Local Economic Development Policies? W.E. Upjohn Institute for Employment Research: Kalamazoo, MI.

. (1992) "The Effects of State and Local Taxes on Economic Development: A Review of Recent Literature," Economic Development Quarterly, 103-111.

Beaulieu, Lionel J. and David Mulkey. (1995) "Human Capital in Rural America: A Review of Theoretical Perspectives," in Lionel J. Beaulieu and David Mulkey (eds.) Investing in People: The Human Capital Needs of Rural America. Westview Press: Boulder, CO., pp. 3-21.

Becker, Gary S. (1962) "Investment in Human Capital: A Theoretical Analysis," Journal of Political Economy, 70, 9-49.

. (1985) Human Capital. National Bureau of Economic Research: New York.

Bergh, Andreas and Magnus Henrekson. (2011) "Government Size and Growth: A Survey and Interpretation of the Evidence," Journal of Economic Surveys, 25, 872-897.

Beugelsdijk, Sjoerd, Henri L.F. de Groot, and Anton B.T.M. van Schaik. (2004) "Trust and Economic Growth: A Robust Analysis," Oxford Economic Papers, 56, 118-135.

Brock, William A. and Steven N. Durlauf. (2001) "What Have We Learned from a Decade of Empirical Research on Growth? Growth Empirics and Reality," World Bank Economic Review. 15, 229-272.

Brock, William A., Steven N. Durlauf, and Kenneth D. West. (2007) "Model Uncertainty and Policy Evaluation: Some Theory and Empirics," Journal of Econometrics, 136, 629-664.

Brome, Heather and Darcy Rollins Saas. (2006) "Reading the Fine Print: How Details Matter in Tax and Expenditure Limitations," New England Public Policy Center Research Report No. 06-3, Federal Reserve Bank of Boston.

Brueckner, Jan K. (1979) "Property Values, Local Public Expenditure, and Economic Efficiency," Journal of Public Economics, 11, 223-246.

. (1982) "A Test for Allocative Efficiency in the Local Public Sector," Journal of Public Economics, 19, 311-331.

. (1983) "Property Value Maximization and Public Sector Efficiency," Journal of Urban Economics, 14, 1-16.

(C) Southern Regional Science Association 2013. 
Caselli, Francesco, Gerardo Esquivel, and Fernando Lefort. (1996) "Reopening the Convergence Debate: A New Look at Cross-Country Growth Regressions," Journal of Economic Growth, 1, 363-389.

Cass, David. (1965) "Optimum Growth in an Aggregate Model of Capital Accumulation," Review of Economic Studies, 32, 233-240.

Clark, Gordon L. (1983) "Fluctuations and Rigidities in Local Labor Markets. Part I: Theory and Evidence," Environment and Planning A, 15, 165-186.

da Silva Costa, Jose, Richard W. Ellson, and Randolph C. Martin. (1987) "Public Capital, Regional Output, and Development: Some Empirical Evidence," Journal of Regional Science, 27, 419-437.

de la Fuente, Angel. (2010) "Infrastructure and Productivity: An Updated Survey," Barcelona Economics Working Paper \#475, Instituto de Análisis Económico, CSIC.

Deller, Steven C. (1990a) "Pareto-Efficiency and the Provision of Public Goods within a Rural Setting," Growth and Change, 21, 30-39. . (1990b) "An Application of a Test for Allocative Efficiency in the Local Public Sector," Regional Science and Urban Economics, 20, 39-406.

Deller, Steven C., Brian Gould, and Bruce W. Jones. (2003) "Agriculture and U.S. Rural Economic Growth," Journal of Agricultural and Applied Economics, 35, 517-527

Deller, Steven C. and Victor Lledo. (2007) "Amenities and Rural Appalachian Growth," Agricultural and Resource Economics Review, 36, 107-132.

Deller, Steven C. and Craig Maher. (2009) "Government, Effectiveness, Performance and Local Property Values," International Journal of Public Administration, 32, 1182-1212.

Deller, Steven C. and Judith I. Stallmann. (2007) "Tax and Expenditure Limitations and Economic Growth," Marquette Law Review, 90, 497-554.

Deller, Steven C., Judith I. Stallmann, and Lindsay Amiel. (2012) "The Impact of State and Local Tax and Expenditure Limits on State Economic Growth," Growth and Change. 43, 56-84.

Durlauf, Steven N., Paul A. Johnson, and Jonathan R.W. Temple. (2005) "Growth Econometrics," in Philippe Aghion and Steven N. Durlauf (eds.), Handbook of Economic Growth. North Holland: Amsterdam, pp. 566-677.

Durlauf, Steven N. and Danny Quah. (1999) "The New Empirics of Economic Growth," in Handbook of Macroeconomics. (eds) John B. Taylor and Michael Woodford. North Holland: Amsterdam, pp. 235-308.

Golan, Amos. (2002) "Information and Entropy Econometrics-Editor's View," Journal of Econometrics, 107, 1-15.

Greene, William H. (2012)Econometric Analysis. $7^{\text {th }}$ ed. Prentice Hall Publishing: Boston.

Goetz, Stephan and Dayuan Hu. (1996) "Economic Growth and Human Capital Accumulation: Simultaneity and Expanded Convergence Tests," Economic Letters, 51, 355-362.

(C) Southern Regional Science Association 2013. 
Henderson, J. Vernon. (1980) "Community Development: The Effects of Growth and Uncertainty," American Economic Review, 70, 894-910.

. (1985) "The Tiebout Model: Bring Back the Entrepreneurs," Journal of Political Economy, 93, 248-264.

Holtz-Eakin, Douglas. (1994) "Public Sector Capital and the Productivity Puzzle," Review of Economics and Statistics, 76, 12-21.

Hulten, Charles R. and Robert M. Schwab. (1991) "Is There Too Little Public Capital? Infrastructure and Economic Growth," American Enterprise Institute Conference on Infrastructure Needs and Policy Options for the 90's, Washington, DC, February.

Johnson, Thomas G., Brady J. Deaton, and Eduardo Serarra. (1988) Local Infrastructure Investment in Rural America. Westview Press: Boulder, CO.

Johnson, Craig L. and Kenneth A. Kriz. (2005) "Fiscal Institutions, Credit Ratings, and Borrowing Costs," Public Budgeting and Finance, 25, 84-103.

Jorgenson, Dale. (1991) "Fragile Statistical Foundations: The Macro-Economics of Public Infrastructure Investment," American Enterprise Institute Conference on Infrastructure Needs and Policy Options for the 90's, Washington, DC, February.

Joyce, Philip G. and Daniel R. Mullins. (1991) "The Changing Fiscal Structure of the State and Local Public Sector: The Impact of Tax and Expenditure Limitations," Public Administration Review, 51, 240-253.

Keely, Louise C., and Danny Quah. (2000) Technology in Growth. Springer US.

Kioko, Sharon N. (2011) "Structure of State-Level Tax and Expenditure Limits," Public Budgeting \& Finance, 31, 43-78.

Koopmans, Tjalling C. (1965) "On the Concept of Optimal Economic Growth," in Tjalling C. Koopmans (ed.), The Econometric Approach to Development Planning. North Holland: Amsterdam, pp. 225-287.

Kornhauser, Marjorie E. (2002) "Legitimacy and the right of revolution: The role of tax protests and anti-tax rhetoric in America." Buffalo Law Review. 50, 819.

Levine, Ross and David Renelt. (1992) "A Sensitivity Analysis of Cross-Country Growth Regressions," American Economic Review, 82, 942-963.

Lynch, Robert G. (2004) "Rethinking Growth Strategies: How State and Local Taxes and Services Affect Economic Development," Economic Policy Institute, available online in May 2013 at http://www.epi.org/publication/books_rethinking_growth/.

McGuire, Therese J. and Kim S. Rueben. (2006) "The Colorado Revenue Limit: The Economic Effects of TABOR," State Tax Notes, 40(6), 459-473.

Mincer, Jacob. (1962) “On-the-Job Training: Costs, Returns and Some Implications," Journal of Political Economy, 70, 50-79.

Minoiu, Camelia and Sanjay G. Reddy. (2010) "Development Aid and Economic Growth: A Positive Long-run Relation," Quarterly Review of Economics and Finance, 50, 27-39. 
Mofidi, Alaeddin and Joe A. Stone. (1990) "Do State and Local Taxes Affect Economic Growth?," Review of Economics and Statistics, 72, 686-691.

Mullins, Daniel R. (2004) "Tax and Expenditure Limitations and the Fiscal Response of Local Government: Asymmetric Intra-Local Fiscal Effects." Public Budgeting \& Finance 24 (4), 111-147.

Mullins, Daniel R. and Bruce A. Wallin. (2004) "Tax and Expenditure Limitations: Introduction and Overview," Public Budgeting \& Finance, 24(4), 2-15.

Munnell, Alicia H. (1992) "Policy Watch: Infrastructure Investment and Economic Growth," Journal of Economic Perspectives, 6(4), 189-198.

Nijkamp, Peter and Jacques Poot. (1998) "Spatial Perspectives on New Theories of Economic Growth," Annals of Regional Science, 32, 7-37.

Oates, Wallace E. (1969) "The Effects of Property Taxes and Local Public Spending on Property Values: An Empirical Study of Tax Capitalization and the Tiebout Hypothesis," Journal of Political Economy, 77, 957-971.

Pack, Howard. (1994) "Endogenous Growth Theory: Intellectual Appeal and Empirical Shortcomings," Journal of Economic Perspectives, 8(1), 55-72.

Partridge, Mark. (2005) "Does Income Distribution Affect U.S. State Economic Growth?," Journal of Regional Science, 45, 363-394.

Poterba, James M. and Kim Rueben. (1999) "State Fiscal Institutions and the U.S. Municipal Bond Market," in James M. Poterba and Jürgen von Hagen (eds.), Fiscal Institutions and Fiscal Performance. University of Chicago Press: Chicago, pp. 181-208.

Poterba, James M. and Kim Rueben. (1999b) Fiscal Rules and State Borrowing Costs: Evidence from California and Other States. Public Policy Institute of California: San Francisco.

Poulson, Barry. (2005) "Grading the States' Tax and Expenditure Limits: A Fiscal Discipline Report Card," Americans for Prosperity Foundation. June. Available online in May 2013 at http://www.americansforprosperity.org/includes/filemanager/files/pdf/afp telrank_0705.pdf.

Ramsey, Frank. (1928) "Empirics for Economic Growth and Convergence," European Economic Review, 40, 543-559.

Ratner, Jonathan B. (1983) "Government Capital and the Production Function for U.S. Private Output," Economics Letters, 13, 213-217.

Reed, W. Robert. (2008) "The Robust Relationship between Taxes and U.S. State Income Growth,” National Tax Journal, 61, 57-80.

Resnick, Phyllis. (2004) "Fiscal Cap Style TELs in the States: An Inventory and Evaluation," Center for Tax Policy, University of Denver, available online in May 2013 at http://www.centerfortaxpolicy.org/reports/fiscal_cap.pdf.

Romp, Ward and Jakob De Haan. (2007) "Public Capital and Economic Growth: A Critical Survey," Perspektiven der Wirtschaftspolitik, 8(S1), 6-52.

Schultz, Theodore W. (1961) "Investment in Human Capital," American Economic Review, 51(1), 1-17.

(C) Southern Regional Science Association 2013. 
Shannon, Claude E. (1948) "A Mathematical Theory of Communication," ACM SIGMOBILE Mobile Computing and Communications Review, 5(1), 3-55.

Solow, Robert M. (1956) "A Contribution to the Theory of Economic Growth," Quarterly Journal of Economics, 70, 65-94.

Stallmann, Judith I. (2007) "Impacts of Tax \& Expenditure Limits on Local Governments: Lessons from Colorado and Missouri." Journal of Regional Analysis and Policy 37 (1), $62-65$.

Stallmann, Judith I. and Steve C. Deller. (2010) "Impact of State and Local Tax and Expenditure Limits on Economic Growth," Applied Economic Letters, 17, 645-648.

. (2011) "State Tax and Expenditure Limitations and Economic Performance," Public Budgeting and Finance, 31(4), 109-135.

Straub, Stéphane. (2008) "Infrastructure and Growth in Development Countries: Recent Advances and Research Challenges," Policy Research Working Paper 4460, The World Bank.

Tatom, John. (1991a) "Public Capital and Private Sector Performance," Federal Reserve Bank of St. Louis Review, 73(May/June), 3-15. . (1991b) "Should Government Spending on Capital Goods Be Raised?," Federal Reserve Bank of St. Louis Review, 73(March/April), 3-15.

Theil, Henri. (1967) Economics and Information Theory. Rand McNally and Company: Chicago.

Wagner, Gary A. (2004) "The Bond Market and Fiscal Institutions: Have Budget Stabilization Funds Reduced State Borrowing Costs?," National Tax Journal, 57, 785-804.

Waisanen, Bert. (2010) “Tax and Expenditure Limits-2010," The National Conference of State Legislatures (NCSL), available online in May 2013 at http://www.ncsl.org/issuesresearch/budget/state-tax-and-expenditure-limits-2010.aspx.

Wilson, Rob A. and Geoff Briscoe. (2004) "The Impact of Human Capital on Economic Growth: A Review," in Pascaline Descy and Manfred Tessaring (eds), Impact of Education and Training. Third Report on Vocational Training Research in Europe: Background report. (Cedefop Reference Series 54) Office for Official Publications of the European Communities: Luxembourg, pp. 9-69. Available online in May 2013 at http://www.biblioteca.porto.ucp.pt/docbweb/MULTIMEDIA/ASSOCIA/PDF/IME.PDF.

(C) Southern Regional Science Association 2013. 


\section{Appendix}

Table A: TEL Index Construction

\begin{tabular}{l|l}
\hline \hline Type of TEL & Revenue index \\
& Revenue (all) 2 \\
& Tax Revenues (only) 1 \\
& Expenditure index \\
& Expenditure 3 \\
Appropriations 2 \\
General Fund Expenditure 1 \\
Both \\
Revenue and Expenditure 1 \\
\hline
\end{tabular}

Sum everything below and then break it into three indices and add the points as above based on the type of index.

\begin{tabular}{|c|c|}
\hline Statutory/Constitutional & Constitutional $=1$ \\
\hline Growth Restriction & $\begin{array}{l}\text { Less than or equal to inflation and/or population growth rate } 6 \\
\text { Less than or equal to the rate of personal income growth } 5 \\
\text { Limited to the rate of growth in the state economy } 4 \\
\text { Restricted to a percent of state income } 3 \\
\text { Equal to a share of total revenue or expenditures } 2 \\
\text { No new taxes or fees } 1\end{array}$ \\
\hline Method of Approval & $\begin{array}{l}\text { Constitutional Convention } 4 \\
\text { Legislative referendum } 3 \\
\text { Citizen Initiative } 2 \\
\text { Legislative vote } 1\end{array}$ \\
\hline Override Provisions & $\begin{array}{l}\text { No override allowed } 4 \\
\text { Voter approval to raise taxes and expenditure of surplus wages } 3 \\
\text { Supermajority vote } 2 \\
\text { Declaration of emergency funds } 1\end{array}$ \\
\hline Exemptions & $\begin{array}{l}\text { Budget reserves -1 } \\
\text { Grants -1 } \\
\text { Capital Projects -1 } \\
\text { Debt Service -1 } \\
\text { Court Mandates -1 } \\
\text { Non-recurring general fund appropriations }-1\end{array}$ \\
\hline
\end{tabular}

(C) Southern Regional Science Association 2013. 